“This is an Accepted Manuscript of an article published by Taylor \& Francis Group in Journal of Curriculum Studies 11/02/2016, available online: http://

dx.doi.org/10.1080/00220272.2016.1143530.”

This document has been downloaded from TamPubutafi The Insitutional Repository of University of Tampere

\title{
The Way Ahead for Finnish Comprehensive School? Examining State-Level School Administrators' Theory of Change.
}

MA Sanna-Mari Salonen-Hakomäki is a PhD Candidate in the School of Education, University of Tampere, Finland. Her doctoral dissertation study focuses on building understanding of system-wide curriculum development in the context of Finnish Comprehensive School Core Curriculum Reform, from the state-level viewpoint. (sanna-mari.salonen@uta.fi.)

Dr. Tiina Soini is a Research Director in the School of Education, University of Tampere, Finland. Her research interests are in the learning and well-being of educational communities, with special focus on teacher communities in comprehensive school.

Dr. Janne Pietarinen is a Professor of Teacher Education in the School of Applied Educational Science and Teacher Education, University of Eastern Finland. His research interests are in the educational transitions, pupils and teachers learning and well-being in the context of sustainable school development.

Dr. Kirsi Pyhältö is a Professor of Teacher Education in the Faculty of Education, University of Oulu and a Research Director in the Research and Development Centre for University Pedagogy, University of Helsinki, Finland. Her research interests include learning, well-being and professional agency of in service teachers.

\begin{abstract}
A significant body of evidence shows that the goals of educational reforms are seldom fully achieved. Some research suggests that the problem lies in state-level curriculum reform work that lacks a sufficient understanding of the educational reality. However, views and perceptions among the central architects of the reforms have not been thoroughly studied. This study provides an insight into these views.
\end{abstract}

The data comprises 23 semi-structured interviews with officials from the Finnish National Board of Education (FNBE) who conducted the Finnish Comprehensive School Core Curriculum Reform (2013-2014). FNBE officials' perceptions of the triggers and aims of the reform - considered as their 'theory of change' - are explored with qualitative analysis by identifying issues they wanted to preserve or react to, and the issues that should be worked towards and positioned as goals in the future.

The results show that there is a somewhat shared theory of change among the architects of Finnish curriculum reform. The chief issues considered as things to react to were related to society, whereas the most common aims were related to pedagogy, such as moving away from traditional teaching towards pupil-centred collaborative learning. However, the theory of change was complex and included possibly contradictory elements.

\section{Keywords}

comprehensive school, core curriculum, system-wide reform, state-level school administrators, sustainable school development 


\section{Introduction}

School reforms are seen as central means to react to the challenges of a changing world, and the national curriculum is seen as the main tool for reforming school systems ( $\mathrm{Ng} 2009$, Saracaloğlu et al. 2010, Soini et al. 2013). However, there is a significant body of evidence showing that the goals of school reforms are seldom fully achieved and the results are often unsatisfactory (Fullan \& Miles 1992). This implies a lack of coherence between policy and practice - i.e. an implementation gap, the situation where the intended national goals of the curriculum fail to be implemented by teachers in the complex reality of the classroom. The gap has been suggested to result from a variety of causes in the school system, such as social problems, policy design, organizational arrangements, and the implementers' capacities (Spillane et al. 2002). However, some research suggests that one of the problems lies in state-level curriculum reform work that lacks expert knowledge and a sufficient understanding of the educational reality (Carl 2005, Chan 2010, Kelly 2004, Ramparsad 2005, Rogan 2007). This is true even in school systems - such as Finland's - that are known for their culture of facilitating wide societal discussion in terms of school development (Sahlberg 2011a).

Bridging the implementation gap and launching systemic and consistent change to create meaningful and lasting changes in teaching and learning (Shen \& Ma 2006) requires the construction of shared knowledge about the complex educational reality and the necessity of change (Chisholm \& Leyendecker 2008, Fullan 2007). Moreover, coherence in terms of purpose, a clear, shared vision, and consistency and stability in decision-making (see e.g. Sahlberg 2011a) as well as in terms of the connection, coordination and alignment of ideas (Hammerness 2006, Newmann et al. 2001) within the curriculum - for instance, between the learning goals and assessment methods, and between different subjects - is shown to facilitate sustainable school reform. The aim is also to create a document that has implementable ideas in the school reality (cf. Chisholm \& Leyendecker 2008). Here, the architects of the reform at the state level have a central role in system-wide reforms 
(Datnow 2005, Hamann \& Lane 2002, Westbury 2008). However, their understanding has not been thoroughly studied.

This study focuses on Finland, a country with state-led national curriculum system reform. The Finnish core curriculum of basic education acts as the basis of teaching in every school and classroom throughout the country. A number of actors are at work in curriculum reforms: policy guidance comes from the Ministry of Education and Culture and other political actors, key stakeholders (e.g. the Association of Finnish Local and Regional Authorities and the Trade Union of Education) submit their expectations, and experts in teacher education and local actors involved in development work share their views. All of these parties participate in the process, which is led by officials of the independent governmental agency called the Finnish National Board of Education (FNBE). These state-level school administrators - i.e. the FNBE officials - are the main architects of the Finnish core curriculum reform.

This qualitative study examines the central reform architects' understanding of educational development - more precisely their theory of change entailing the understanding of the triggers and aims of curricular change - in the context of the latest Finnish comprehensive school core curriculum reform (which comes into effect in autumn 2016). Sustainable implementation stems from a shared and coherent understanding of change among the architects of the reform (cf. Newmann et al. 2001) and this approach offers a wider perspective on the understanding of educational change than simply examining core curriculum documents; they are only brief reviews of the ideas behind them, and the end result of negotiations or even power struggles in the decision-making process. Moreover, exploring the architects’ personal as well as shared theories of what should change in education presents an opportunity to understand the ideas and contents that constitute the Finnish national core curriculum, and, therefore, the future of the Finnish comprehensive school. Moreover, at a more general level, it contributes to the theoretical 
understanding of the steering of national curriculum reform and the curriculum as a tool for large-scale school reform.

\section{Theory of Change in Curriculum Reforms}

The 'theory of change' in school reforms entails what needs to be changed and the direction in which the change should be steered (cf. Fullan 2007). Consequently, it refers to the understanding of the reasons motivating and initiating change, referred to here as the triggers of the reform (Merkens et al. 2003), as well as perceptions about the desired direction of the change, referred to here as the aims (Fullan 2007). Issues motivating change may have emerged rapidly or have evolved and developed over a longer period of time, but they are called triggers because they are acknowledged and reacted to in the reform process at that time. Triggers consist of things that are seen as valuable and worthy of being preserved, as well as things that need to be reacted to.

Various triggers for national curriculum reforms have been identified internationally. The national curriculum plays an important role in societal development (Weiler 1990), and consequently, there are various societal needs that curriculum reformers must react to. For example, the national curriculum can be involved in strengthening social cohesion (Al-Daami \& Wallace 2007), redressing social injustices and increasing societal well-being (Bantwini 2010, Chisholm 2005), and promoting equality (Datnow et al. 2000). In addition to reacting to problems and challenges, the curriculum is also a tool to cherish and preserve various elements (Lawton 1973), such as the national culture. For example, the national curriculum is an important mediator of culture and values (Lawton 1973, Saylor et al. 1981) which always makes curriculum reforms highly contextual (see e.g. Kelly 2004, Rosenmund 2000); it is involved in building the nation (Georgescu 2008, Wallace \& Priestley 2011) and reconstructing its identity (Shah 2012).

Another motivator for reforming the national curriculum is the attempt to solve the problems and challenges arising from pedagogy and the circumstances within the educational system. 
These problems include, for instance, fragmentation and poor coverage of cross-curricular issues and poor test scores (Priestley 2011); teaching being based on a fragmented collection of subjects, content, and concepts (Beane 1995); teacher-centred teaching (e.g. Yusuf 2013); and the encouragement of rote learning instead of focusing on critical thinking and how to use knowledge (e.g. Rogan 2007). Furthermore, some national curricula have been criticized of being too narrow (Broadhead 2001, Brundrett \& Duncan 2011), especially in the cases of standards-based reforms that aim at alignment (Koretz 2005). Functional pedagogical solutions act as a basis for preservation during the curriculum reform.

The aims of the reform, on the other hand, show the desired future direction of the development. Aims refer to issues that should be added, strengthened or positioned as goals in the future; they possess the idea of 'working towards' something. Among many of the presented triggers, trends, problems and requirements, various new aims and goals for education in terms of the national curriculum are often identified. For example, attractive goals in curriculum reforms include active learning (Korkmaz 2008), student participation (Li \& Ni 2011), learner-centredness (Bulut 2007, Chisholm \& Leyendecker 2008, Yusuf 2013), the integration of subjects and knowledge (Li \& Ni 2011, Priestley 2011, Wallace et al. 2007), and effective learning processes (Albright et al. 2013). There is also a constant effort to increase students’ knowledge (Korkmaz 2008) and skills (Bantwini 2010, Ni et al. 2011), and to improve school achievement (Altinyelken 2010, Cheung \& Wong 2011, Datnow et al. 2000). New understandings about learning (see e.g. Arslantas 2011, Ng 2009) continually guide attempts to reform curricula.

There are different ways to theorize these various approaches to reform. Some basic theoretical divisions and classifications are usually put forward in literature on curricula, such as student-centred, society-centred, and knowledge-centred perspectives (Walker \& Soltis 1997), and scholarly academic, socially efficient, learner-centred, and social reconstruction (Schiro 2008). Curricula may also be viewed through the lenses of procedures or objectives, referring to the 
philosophical distinction between the process of education and the predetermined goals of education (Bobbitt 1972, Stenhouse 1975, Tyler 1949). There have also been attempts to combine these perspectives and to view them as complementary (Hardarson 2013, see also Lawton 1973). In terms of control, the national curriculum may be observed through traditions of process versus product control, establishing, for example, different responsibilities for teachers (Hopmann 2003). Input-based process control allows greater pedagogical freedom and is based on the teachers' professionalism; in contrast, product control emphasizes the teachers' efficiency to deliver the curriculum and produce outcomes (Hopmann 2003, Molstad 2015).

Some critiques have also raised the question of whether the motivators of curriculum reform are mostly the consequence of the inevitable evolution of market policy-led neoliberal time in the Anglophone world (see e.g. Priestley \& Biesta 2013). The national curriculum has, in recent years, been noted to be submissive to various powers outside the school system, and curriculum reforms are often being interpreted as policy-driven (Fernandez et al. 2008). By increasing human skills and capital, education is strongly tied to economic advancement and the need to sustain economic growth and promote national competitiveness are strong drivers of educational change (Albright et al. 2013, Chan 2010) in the context of the changing world and its complex challenges. However, when curriculum is more and more about answering to the societies' economic needs, curriculum's traditional role and tasks in education as a producer of wider civilization and citizenship might be changing as well. The movement towards a pupil-centred, collaborative, modern way of seeing learning and abandoning the basic ideology of traditional learning is sometimes interpreted as a part of this neoliberal rhetoric (cf. Priestley \& Biesta 2013). This refers to the role transformation of pupils and parents to clients who are claiming the school to provide various future skills for their individual needs to survive in the labour market and the market-led world. This raises the question of whether the school, and the curriculum, is actually a servant of the 
needs of markets and policies - or is it still executing its traditional responsibility as a place for individuals’ growth into civilized, critical citizens?

\section{Curriculum Reform in the Finnish Context}

This study focuses on the core curriculum reform in Finland - a country that has managed to create a rather successful education system. Results in international comparisons (e.g. PISA) have indicated that the system works, at least according to the measurements made. Differences between individual schools have been among the lowest in the world and the pupils' results have been good, even though Finland has not adopted the idea of accountability testing and relies on sample-based assessment. This is highly coherent to the strongest acknowledged cultural goal of the Finnish school: equality. The idea of educational equality as the main strategy of the welfare state characterizes the history of curricular thinking and the goals of education in Finland; in addition the importance of equality, it has been acknowledged that in a small country, it is crucial to get everybody educated and, hence, integrated to society. (See e.g. Simola 2005, Sahlberg 2011a, 2011b)

Finland has therefore made some distinctive choices when compared to other Nordic countries when trying to avoid streaming and the division of pupils at an early age (Basic Education Legislation 628/1998, Vitikka 2009). There are no national testing systems or school ranking lists in basic education, and the evaluation of implementation is based on samples. As Sahlberg (2011b) points out, Finland has not joined the global education reform movement (GERM) nor has it embarked on outcome-based education (OBE). Instead, it has created its own way of developing schools, the so-called 'Fourth Way of Finland' (Sahlberg 2011b, see also Hargreaves 2007, Hargreaves \& Shirley 2009).

In the Finnish school system, the core curriculum is the central system-wide steering strategy of basic education (Vitikka 2009), and state-led reform occurs approximately every ten 
years. The document constitutes - in addition to the core content of subjects - the general principles and approaches to themes like learning, learning environments, welfare, assessment, and special needs. Core curriculum reform work is based on the Finnish Parliament's decision on the distribution of lesson hours: the Ministry of Education and Culture prepares and presents the decision and representatives in Parliament make the final decision of which subjects are included in curriculum and how many lessons per week these subjects are taught in every classroom. This political decision acts as a basis for the core curriculum reform work, which is allocated to an independent state-level development agency, namely the Finnish National Board of Education (FNBE). The FNBE has total responsibility and power over preparing the core curriculum reform work (Finnish National Board of Education 2015a, 2015b) based on the performance agreement with the Ministry of Education and Culture. Thus, the central state-level school administrators - i.e. the FNBE officials - hold a key position in the reform as both decision-makers and central executors of the reform. Compared to many countries, Finnish curriculum reform is then actually led by officials, not politicians, possibly enabling a more sustainable development that could be less vulnerable to changing political influences and interests.

Core curriculum reform is an overarching, system-wide process. In the latest curriculum reform (see Finnish National Board of Education 2015a) hundreds of stakeholders - for example, representatives from universities, schools, and associations, such as the Finnish Parents' League - were invited by the FNBE to participate in the core curriculum reform working groups and seminars. The steering group, composed of different stakeholders and led by the head of FNBE, commented on and guided the work of the working groups regularly to ensure that various perspectives were taken into account when compiling the document. There were also wide opportunities for public comments; indeed, all citizens were encouraged to comment freely on the drafts online, and more structured feedback was collected from schools and municipalities as well. 
The finalized core curriculum document then serves as the basis for local implementation at the district, municipal and school level. The implementation strategies of the reforms have varied throughout the history of comprehensive school: strategies started out with a rather centralized model (from the 1970s to the 1980s), evolved towards a model that emphasized locality (in the 1990s) and reverted to a more centralized model (in the 2000s) (Nevalainen et al. 2001, Sivesind 2010, Vitikka 2009). Currently, the system is relatively decentralized and relies heavily on school autonomy and empowering schools and teachers in reform work (Sahlberg 2011a) and it could be viewed as representing the tradition of process control (Molstad 2015). In the reality of the classroom, teachers as trusted, highly educated agents of change, and they have autonomy to form their final interpretations of the document and make creative pedagogical choices within the curricular framework (Gerrard \& Farrell 2013, Sahlberg 2011a, Toom \& Husu 2012). Moreover, Finnish core curriculum has been explicitly committed to socio-constructivistis view on learning (Niemi, Toom \& Kallioniemi, 2012).

However, the uniqueness of the Finnish system needs to be examined critically. Critics have pointed out that Finland actually has a strong neoliberal policy, though it was introduced rather late compared to other western countries (Simola et al. 2013), and curriculum planning is primarily seen to serve the requirements of global economic competiveness (Saari, Salmela \& Vilkkilä 2014). From this viewpoint, the curriculum reflects the global drivers of education, such as outcomes-based education (see e.g. Ramparsad 2005, Rogan \& Aldous 2005) and innovation policy (OECD 2012, 2013). For example, a stronger focus on competitive opportunities for the more able pupils over the weak can be interpreted as part of the international neoliberal rhetoric (see e.g. Johannesson et al. 2002).

\section{Mapping Reform Architects’ Understanding}

In sum, the direction of the curriculum reform is guided by complex reasons or causes motivating, invoking and inciting change that reformers observe coming either from within 
pedagogy or the school, or from outside the system - from societal development - and it is therefore highly contextual (cf. Rosenmund 2002). The national curriculum has various tasks and meanings that are concretized in reform attempts: the curriculum should be developed in a way that preserves the positive aspects, reacts to possible challenges and proactively works towards desirable goals at the same time. But how are the various aspects of change understood among the main architects of curriculum reforms?

In the context of national curriculum reform, the curriculum architects' understanding of the circumstances and reasons motivating and triggering change - as well as their perceptions about what needs to be changed in the curriculum - provide a baseline for state-led system-wide curriculum development. The theory of change behind the more general ideological view of the curriculum may have a greater effect on the actual implementation of the curriculum reform, whereas the principles or curriculum theories presented in the theory might or might not be acknowledged and adopted by the central reformers.

In this article, we aim to describe and analyse the theory of change of core curriculum architects by exploring the following research questions:

1. What do the state-level school administrators at the FNBE perceive as the triggers and aims of the current reform of the National Core Curriculum of Basic Education?

2. How shared perceptions of triggers and aims are among FNBE officials?

In addition, we discuss what the shared or contradicting perceptions indicate in terms of the national curriculum as a tool for educational change.

\section{Methods}

\section{Participants}

Twenty-seven administrators from the FNBE - constituting a group of experts in the vantage points and power positions in basic education - were requested to participate in this study. These 
individuals were chosen as informants because they acted as chairpersons, secretaries or presenters in the core curriculum reform working groups. Therefore, they represent different perspectives of the working groups and worked as central executers of the reform. Some administrators had several roles and memberships in multiple groups. Altogether, 23 administrators participated in the study (including 6 men and 17 women). Four administrators did not respond to interview requests, so the response rate was $85.2 \%$.

The officials chosen to conduct the core curriculum reform have the requisite education, central positions, and essential experience-based expert knowledge (see Bogner and Menz 2009). They had worked at the FNBE for varying lengths of time, ranging from only a few years to over 25 years. The majority (17/23) had worked previously as teachers and had teacher competence; some had leadership studies or experience of working as principals or chief education officers, and some had experience as teacher educators or researchers as well. Most of the administrators (16/23) had previous experience of core curriculum reform work, and some had previously worked in municipal- or school-level curriculum implementation.

The data were collected using semi-structured interviews (Patton 1990). Participants were informed of the study before its launch: the purpose of the study was introduced to the administrators at a FNBE meeting in the spring of 2013. After this, in the autumn of 2013, email requests - which also contained basic information about the study - were sent to the administrators. Two reminder messages were sent in order to decrease the loss of participants.

\section{Instrument}

The interview protocol was developed in 2013, and it was piloted and revised before data collection.. The interview aimed at gaining an overall picture of administrators' views about the reform including their theory of change, and included six themes: the aims of the reform, the core curriculum reform process as a whole, group work within the reform, the interviewee's role in the process, the interviewee's thoughts on the local implementation, and the meaning of the reform. 
Altogether, the interview comprised 50 questions, 14 of which were especially essential concerning the research problem of this study. Questions included in the data analysis can be found in Appendix 1.

In addition, background questions on work experience and participation in previous curriculum reforms, were addressed. Participants were also given an opportunity to reflect on any other subject related to the reform, to ask anything, and to comment on the interview at the end of each interview session. Some participants used this opportunity to clarify or fulfil their views of discussed themes, some wanted to ask more about the research project itself. No new themes were raised.

The interviews were conducted over a one-month period between October 2013 and November 2013 by the authors of this study.The core curriculum making-process was lauched in 2012 and the core curriculum document was schleduled to be finalized and officially accepted until the end of year 2014. So the interviews were conducted in the middle of the core curriculum reform process, when the first drafts of the general principles of the core curriculum were complete and the subject groups were working with the subject parts of the curriculum based on those principles. The duration of the one-to-one interviews was approximately an hour, however, varying between 45 and 90 minutes. The interviews were recorded and fully transcribed for analysis.

\section{Analysis}

All the interviews ( $n=23)$ were carefully read to ensure familiarity with the data. Building the coding procedure and criteria entailed a pilot analysis in researcher triangulation, consisting of four interviews that were first coded by the first author and then re-coded by other authors to ensure better validity in interpretation. Discrepansies were discussed and common concensus was built of what segments to include in the analysis and how to interpret them. In all, 930 segments, referring to phrases or combinations of words that formed a unity of thought in our 
interpretations, were included in the analyses. Analysis was conducted by the first author but compatible for all of the authors during the analysis process.

During the first analysis phase, an inductive within-site analysis strategy (Miles and Huberman 1984) was adopted to analyse the included segments from each interview to identify all of the emerging issues that the informant talked about. Analysis aimed at forming descriptive, encompassing categories that were respectful to what the informant had said and the terminology he had used (cr. open coding, Glacer 1978) in the interview, to avoid making too early theory-based interpretations of the data. These categories are referred to here as 'issues'. By going back and forth between all of the interview transriptions, given codes and categories, 258 issues were named.

During the second phase, a deductive analysis strategy was introduced to categorize the data into triggers and aims, based on theoretical understanding of the concept 'theory of change'. Triggers entailed all issues that referred to things motivating change. They were coded into two categories: preserving something or reacting to something. Issues about the aims of the reform, referring to what should be added, strengthened or positioned as goals in the future, were coded as working towards something.

During the third analysis phase, triggers and aims were analyzed based on the context of the mentioned trigger or aim. These categories were formed using abductive approach: pretheoretical understanding resulted first two categories for analysis: issues inside and outside the school system, referring to the categories school and society. However, working with the data led to create a third category, pedadogy, to better divide pedagogical and organizational aspects from each other. These three categories - pedagogy, including pedagogical principles, practices and contents of the reform; school, entailing organizational structure, culture, and the actors of the school; and society, consisting of expectations and changes in both the local and the global environment outside school - acted as context categories to which the issues were divided in during the analysis. 
During the fourth phase, the 258 issues placed in these categories were analysed further to form thematic entities. Themes were built up based on both a pre-theoretical understanding of the issues and also by constantly returning to the data to look for relatedness, causal connections, and central ideas, combining the issues with more abstract themes. As a result, 44 themes were formed.

During the final phase of analysis, to explore the coherence of the participants' perceptions, themes within sub-categories were analysed based on how many of the informants shared the same idea of a trigger or aim (cr. cross-site analysis, Miles and Huberman 1984). The analysis resulted in four categories: not/weakly shared (shared by $\mathrm{n} \geq 5$ ), partly shared (shared by $\mathrm{n}=6 \geq 11$ ), strongly shared (shared by $\mathrm{n}=12 \geq 18$ ), and fully shared (shared by $\mathrm{n} \geq 19$ ) themes.

\section{Results}

\section{Triggers and Aims in State-Level School Administrators' Perceptions}

Administrators brought forward 258 different issues, including things to preserve, react to, and work towards, in the curriculum reform, across the three distinct levels of pedagogy, the school, and society. The results (see table 1) show that administrators highlighted a total of 166 issues triggering the reform and 92 aims for the reform (altogether 258 issues).

\section{Insert table 1 about here}

Notably, issues that need to be reacted to were emphasized the most $(108 / 258)$. The majority of the issues arise from society - for example, a lack of resources in education and increasing societal needs. There were also multiple issues at the school-level that administrators were worried about, such as schools being too old-fashioned. Issues to react to in pedagogy were smaller in number, but problems, such as subject-centredness, were highlighted. 
As expected, administrators also identified various aims, referring to issues to work towards (92/258). Most of them were pedagogy-focused. For example, administrators highlighted the aims of increasing pupil-centredness and better integrating teaching content. Furthermore, at the school-level, aims like increasing teacher collaboration and clarifying school values were mentioned. Societal aims, such as schools being producers of future competences, were noted as well. The number of things noted by administrators to preserve (58/258) was only half of the number of things to react to or to work towards. These issues were mostly located in the school system - for example, the wish to cherish teachers, pupils ' well-being, and the basic structure of the school.

\section{Triggers and Aims in Pedagogy}

Of the 258 issues, 44 themes relating to triggers or aims were formed. Many themes were mentioned frequently and by numerous administrators. At the level of pedagogy, fully shared themes emerged in both triggers and aims (see table 2).

\section{Insert table 2 about here}

Somewhat surprisingly, the results indicated that the appreciation of current good quality teaching and teacher student interaction was not among the most shared themes. Instead, administrators fully shared the perception that the teacher-, classroom-, and text book-oriented traditional approach to learning was something to react to. Thus, administrators fully shared the aims of pupil-centred and collaborative learning, referring, for example, to pupils' individual support, active participation, problem-solving, and cooperative tasks in various learning environments with the help of the teacher. This is how Interviewee D describes the change:

'So, in a way, it is all about this pedagogical change. And I think that we have had it on-going in a good way here for a long time. ... It would bring about pupil-centredness and working methods 
that support learning by doing, change the teacher's role, enable the utilization of new technology, make it possible to get away from the rush. It would meet the various challenges that we have here now, and focus on what is done and how to do it. ... And then, we are pretty much getting under the skin of the teachers.' (Interviewee D)

Related to this, a strongly shared concern was that the subject-centred approach to education still dominates. Administrators also strongly emphasized the aims of developing teaching contents towards more meta-level and integrative pedagogy, and increasing interaction between subjects. Moving towards more integrative pedagogy was an appreciated approach in Interviewee J's thinking:

If so far we have been thinking about what to teach, then it is easily subject-centred. Not necessary narrow-minded... but it could mean that the only thing that matters to us is our own subject... but it is probably the school and education, to see the forest for the trees. And I think this is an important question if we think of the curriculum as a ship and we are navigating it in a new direction. If we are going that direction, we can get rid of this danger of causing a narrow-minded purely subject-centred approach and see the school through its broader task of teaching and educating. That is the school's task, our cooperative task as professional educators. I see that as a big, desirable goal. (Interviewee J)

On the other hand, the administrators partly shared a willingness to preserve the individual strong, science-based subjects that produce essential and deep know-how, and they strongly shared the idea of developing the subjects further.

Another theme among the results is assessment. Weakly shared views included aiming for more versatile evaluation that would be better aligned with pedagogy, and increasing parity in assessment. Worries about problems in evaluation, such as outdated methods, were weakly shared as well. Although only a weakly shared issue, some administrators pointed out that nonstandardized assessment is a cherished choice. The opportunity of working towards standardized evaluation was not mentioned even once - on the contrary:

Finland has so much to give to the international conversation because, for example, our way of thinking about evaluation is way different from [that used] in most countries. Thank God we do not have national tests in comprehensive schools and no school inspections. That is why we have saved ourselves from multiple threats. (Interviewee L) 


\section{Triggers and Aims in the School}

At the school-level, administrators strongly shared views on various triggers and aims (see table 3).

\section{Insert table 3 about here}

Administrators strongly shared the perception that overall, Finnish schools are good, and this was reflected in a very general level in many interviews. The system has a good basic structure and it functions well. More precisely, there was strong consensus that certain things in the system should be preserved, such as skilful teachers who have autonomy and the great trust in the Finnish system, as interviewee A notes:

Yes, we have good teachers. ... A teaching career is such a desirable, interesting position, and I think that is a very important thing. Our progress and our great results are probably based on the fact that we have good teachers because good pupils apply to teacher education. (Interviewee A)

Another strongly cherished theme was the appreciation of Finnish schools’ equality and minimum selection that the interviewees high-lighted. Administrators pointed out that there are no ranking-lists of schools and kids are going to their local comprehensive school. Consequently, some of the administrators shared the concern that this cherished equality is being eroded due to school choice, individualism, and decreasing resources at the municipal-level. However, preserving equality and supporting each child as an unique individual were not seen as contradictory aims, as Interviewee M clarifies:

Well, first of all, the Finnish comprehensive school is everyone's school, each pupil's school. And I am strongly committed to this comprehensive school ideology, meaning regional, financial and gender equality. And because the Finnish school is everyone's school, it indicates that the differences in pupils' learning abilities - as well as their family situations in terms of happiness and worries - need to be taken into account in teaching. (Interviewee $\mathrm{M}$ )

An appreciation of decision-making and the reform of the system's structure was strongly shared, and the system-wide, on-going cooperative school development was seen as part of this. However, disappointment in decision-making in education was also partly shared. This related, 
for example, to the core curriculum, which the administrators felt was failing to respond to teachers' needs as being too loose, too tight or otherwise disappointing. They strongly shared the idea that a strong pedagogical support via coherent, functional curriculum and pedagogical leadership would serve teachers better. Thus, administrators partly shared the perception that schools' missions and values needed to be clarified.

Nevertheless, the administrators strongly shared the concern that schools with their practices and equipment, are outdated, isolated institutions far away from pupils' world and life reality. Also strongly shared was the view that decreased levels of experienced well-being among both students and teachers were problems to address. Related to this, administrators strongly shared the aim of fostering collaboration and interaction within schools, and also with the wider environment, like different communities.

\section{Triggers and Aims in Society}

At the societal level, administrators' perceptions of things to react to and work towards had strongly and fully shared themes (see table 4).

\section{Insert table 4 about here}

Administrators fully shared the view that the world is changing, and challenges like globalism, changes in labour market, and digitalization put various expectations on education and schools. The idea of schools as providers of various competences and skills for the present and future was fully shared, referring to for example to various problem-solving skills, labor market's desired competences and everyday skills. Various societal needs were strongly positioned as challenges to react to. These entailed issues like family problems and the challenges of the aging 
and retirement of masses within few years. Partly shared was the more traditional idea of school as a source of individual growth and citizenship. This was reflected by the Interviewee D:

Of course we need to take the learner's own circumstances, desires and so on, into account. But I think that in the world and in society, everything cannot be totally free. There are some baselines, and the payer - society in this case - has his or her own wishes about what kind of know-how is needed and what direction to work in. And based on all of these perspectives, we create an outlook on the core curriculum. (Interviewee D)

However, administrators strongly shared the concern that school is facing various expectations and challenges without proper resources, and a lack of political support was also mentioned, as Interviewee $\mathrm{C}$ reflects:

I am terrified that we'll have to provide a great education and be the most competent nation in 2020, but that there shouldn't be any costs. At least, I know that teachers feel like that. How is it possible that there are so many great expectations for schools? It is important but... there doesn't seem to be enough money. To develop it ... it is not something that just happens, it takes time and resources. But it seems that resources are decreasing...' (Interviewee C)

Another strongly shared perception was that Finnish schools have a good reputation and position when compared internationally, for example, due to the miraculous PISA-success of the Finnish school noticed all over the world. Administrators talked about various international visitors they had entertained, various studies they had read and the overall appreciation they had interpreted existing towards the Finnish system. Administrators also partly shared the view that schools and education are currently highly appreciated within Finland, as well.

Administrators had contradictory opinions regarding teacher education: appreciation of the Masters qualifications and strong, varied programmes at universities was partly shared, while the worry that these features might be outdated or too detailed was weakly shared. However, a link between good teacher education and successful school system was notified. 


\section{Discussion}

\section{Theory of Change in the Finnish Context}

So what do these results actually tell us about educational change in the context of curriculum reforms? Schools across the world are facing multiple expectations from their respective societies (Fernandez et al. 2008) and Finland is no exception, as the results clearly indicate. Our results suggest that schools are seen as producers of the numerous skills and competences that pupils will need in the present and future (cf. OECD), but there is an undercurrent of concern that Finnish schools are outdated institutions failing to meet the realities of pupils' everyday lives. In their views about the direction of change, administrators also highlighted the current issues with well-being at

school. This is in line with the prior research indicating increasing signs of pupil disengagement and a decrease in the well-being of both pupils (National Institute for Health and Welfare 2013) and teachers (Pahkin et al. 2007, Soini et al. 2012) in Finnish schools. The administrators' theory of change reflected the growing pressures in keeping up with the changing environment and responding to the needs of future generations.

To face the challenges of the change, the architects of the reform seem to clearly recognize the general strengths of the Finnish education system. The most appreciated elements shown in the administrators' theory of change, such as the structure of the system, seem to be consistent with previous literature about the success of Finland, along with the less-shared elements like the non-standardized testing. Moreover, consistent with previous research on school development (Pyhältö et al. 2012, Sannino 2010, Toom \& Husu 2012), our results show that teachers with Master's-level education, competence, and appreciation are placed in the limelight and given responsibility for pedagogical challenges.

However, our results show the administrators' concern about the decreasing resources and non-supportive politics in education; better resources and political decisions from the Ministry 
and Parliament are needed in order to provide, for example, tools and training for the new curriculum and support for its implementation equally across the country - not just in the most vibrant municipalities. As international studies also indicate, the counterpart of trust can be that teachers are left alone in schools to manage with change (Bantwini 2010, Chan 2010, Cheung \& Wong 2011) without proper resources (Bulut 2007, Georgescu 2008, Korkmaz 2008). On the other hand, the collaborative nature of school development was noted as one of the strengths of Finnish schools, and as our results show, that crucial element of theory of change is a shared goal to increase collaboration in schools among the teaching staff, and with wider multi-professional networks and parents.

Our results show that even though administrators' theory of change places strong trust to good teachers they do anticipate some challenges with the forthcoming pedagogical changes. The discussion of future skills and competences (OECD) seems to conflict with the traditional discipline-based teaching tradition that will remain a part of the Finnish system, and based on the results, this must be reacted to. Our results show that the direction of Finnish education is towards teacher-facilitated collaborative learning, and away from traditional teaching where the teacher transmits the knowledge. The change towards pupil-centred collaborative learning can be interpreted as a strong reflector of the Anglophone world's neoliberal trend in pedagogy (cf. Priestley \& Biesta 2013) or as an implication of research tradition of socio-constructivistic learning (cf. Core Curriculum for Basic Education 2004, Toom \& Husu 2012). Our results show that the architects of the Finnish curriculum reform consider these shared pedagogical aims more as questions of effective and meaningful learning that reflect the overall commitment to socioconstructivistic orientation than any policy-driven goals of school.

Moreover, our results also show a parallel appreciation towards both strong science-based subjects and more integrated learning units; developing them both was seen as important. The controversy between subject-centredness and integrative approaches is an issue of 
the learners’ position, and it reflects the pupil-centred romantic and subject- or teacher-centred traditional ways of curriculum thinking (Cuban 1992, Dewey 1959, Jackson 1992, Lawton 1973). At least these results seem to indicate that both belong to the present and the future of education in Finnish schools. The relevant question to ask seems to be 'how does modern teaching fit the Finnish system and its desire to preserve traditional subjects?'

The Finnish system is strongly built on the ideal of equality, and this ideal is now facing challenges. Indicators show that differences between pupils are actually increasing (Bernelius 2011, Salmela-Aro et al. 2008) and administrators highlight that active work is required to maintain equality in schools to ensure they offer the same opportunities to all pupils regardless of their home town, gender and socio-economical background. But how is it possible to offer the same opportunities to all if the future aim is to move towards child-centred approaches? These are not necessarily seen as contradictory aims, though their relationship needs to be clarified. In the international context, pupil-centredness is often interpreted as providing support to embrace and develop pupil's talents: the result of this is parental choice among schools, ranking lists, growing differences in pupil achievement and even an equality gap in society (cf. Sahlberg 2011). In contrast, results show that in Finland the aim is the opposite - to avoid early division of pupils and offer each pupil equal opportunities to succeed in life by taking care of special needs in each school.

Moreover, in administrators’ theory of change pupil- and child-centeredness was understood as an aim to better support different learners' needs and well-being rather than focusing on strongly individualistic perspectives and choices; this refers to the fact that Finnish schools have been criticized for treating pupils too homogenously and there have been discussions of how to support pupils with special needs or talents better - i.e. to support the equal opportunities to ensure that everyone can succeed (Sahlberg 2011). This reminds us that also internationally shared concepts and aims are always interpreted differently in each country and culture (cf. Rosenmund 2005) and they cannot be used blindly as indicators of educational strategies. 
The future of the Finnish education is in the hands of the policy-makers and architects of the reform - along with everyone working at every levels of the school system. Our results indicate that educational imagination, creative solutions and new ideas are required to maintain the high quality and equality of education, especially since resources are diminishing. Is the future solution for schools to have greater cooperation outside of schools, for example with communities (cf. Engeström 2015)? Should schools form tighter alliances with each other? Is the solution stronger or lighter national steering? In light of the results, it seems that the way ahead still rather strongly relies on the principles of the Fourth Way education strategy, based on professionalism, trust and shared responsibility (see Hargreaves \& Fink 2009, Sahlberg 2011a) rather than the neoliberal ideas of accountability, OBE or standardized testing that have not been accepted as the future direction for the Finnish school.

\section{Coherence in Theory of Change}

A meta-level perspective of the results shows that the central architects of the Finnish core curriculum reform - the state-level school administrators - have a rather consensual theory of change, i.e. an understanding about the triggers and aims of change. This theory of change reflects the basic tension always present in the curriculum, and in fact in education: how does one both preserve and maintain valuable knowledge and good, functional structures, and, simultaneously, change, reinterpret, and reform them to better serve society - even when they are somewhat contradictory? Indeed, education must not simply keep up with the demands of the world; it must proactively steer development for the future. In this study, the understanding of triggers and aims reflected a rather shared idea of the way ahead for the Finnish comprehensive school. The consensus indicates that either the state-level school administrators actually have a very similar understanding of the future of education based on their career tracks, education and other experiences, or this shared understanding has been built successfully in the reform. In either case, 
based on this strong consensus, it is relevant to claim that these are the actual challenges and ongoing change processes in curriculum reform at the moment.

Moreover, as we discovered, the reform architects' theory of change was complex and included possibly contradictory shared elements - even at the level of individual participant's reflections - such as subject-centredness and integrative approaches. This is a useful reminder of the slow and complex nature of change processes and also human understanding of them. Whereas the theory of change stems from architects' experiences and both personal and professional ideas of the world and education, it can collaterally entail contradictory elements and elements of multiple parallel theories or ideal models of education and reforms. Time will tell if these tensions and complexities are actually transitions in one direction or another, or whether these seemingly contradictory elements can exist in parallel and even complement each other (cf. Hardarson 2013, Lawton 1973). Some conflicting views are always present in the dynamics of school systems (Beane 1995, Chin 1976, Schmidt \& Datnow 2005), and in fact, constructive disagreements may lead to more considered results and decisions. However, acknowledging and considering these tensions is important. If the tensions in the shared theory of change are transformed in the final curriculum document, the major responsibility for interpreting and making choices among them is placed on teachers during the implementation. There is also the risk of letting these contradictions remain in the curriculum, perhaps even meaning that pupils themselves have to negotiate them when they try to build their coherent learning paths in the day-to-day context of the school (Biesta 2013).

\section{Conclusion}

Due to pressures from society and global markets, it is increasingly important to understand what is regulating educational reforms. The concept of the theory of change is presented here as a tool to analyse the understanding of triggers and aims in curriculum reforms. Moreover, we argue in particular that the state-level administrators' theory of change plays a crucial role in affecting 'the 
inputs' in terms of the national curriculum (see Molstad 2015). More precisely, the decisions about the contents of the curriculum are steered based on their understanding. It may be argued that in reforming the educational system, it is essential to reflect and be aware of the contents of the main architects' theories of change.

Methodologically, we encourage the development of the analysis framework of the 'theory of change' for further approaches. The categories used in the study of the theory of change i.e. things to preserve, to react to and to work towards on the levels of pedagogy, the school and society - can be utilized as analytical categories in other contexts as well. However, a context-sensitive approach is recommended, because the levels of pedagogy, the school and society form a complex system and they are intertwined in many ways. Separating them enabled comparison and context-specific examination, but also a more relational approach would be complementary. Inductive within-site analysis within the categories, on the other hand, provided a penetrating analysis, enabling us to discover the contents of the participants' understanding of change.

Moreover, the contents of reform architects' theory of change are strongly contextual, reflecting society and culture as well as the ideological principles adopted over the educational track, career and experience of the system. Therefore, understanding the national school system and the structure of the particular curriculum reforms, as well as the national culture and history behind the solutions (see Lawton 1973), is crucial. Reforming the curriculum is a central part of school development in Finland, but it is used in conjunction with other factors, such as educational policies in national and local settings, teacher education incentives and the pedagogical reality (cf. Alok 2012). Therefore, theories of change among other agents of school reform - such as teacher educators, policy-makers, chief education officers, teachers and key stakeholders - also offer interesting insights into the state and future of education. It would also be useful to explore whether there is a shared theory of change across the different agentic levels of a single school system. 
Finally, the theory of change is only one half of the equation in complex curriculum reforms. Deeper understanding of the theory of change may help us to better understand the possible problems of implementation, and to create a more coherent 'theory of changing' - i.e. the means by which the change is brought about (see e.g. Chin 1976). The current complexity and challenges in the theory of change, referring to the tensions or contradictory elements that we found in this study, involve the importance of the curriculum-making process. In this process, the understandings of triggers and aims are recognized, negotiated and either included or excluded in the final core curriculum document in order to form a unified, coherent steering strategy for education; thus, they are not left to teachers to resolve alone in the reality of the classroom. With this in mind, it is important to examine the actual curriculum-making process: how is this process conducted and what regulates it? In all, a deeper understanding of the theory of change and the theory of changing among architects of reform would consequently result in the greater understanding, meaningfulness, and commitment of those implementing reforms in the field (Korotkov 1998). Furthermore, it might help to build more coherent and sustainable educational reforms in the future.

\section{Acknowledgements}

This study is part of the larger national 'School matters' research project (2014-2018) funded by the Finnish Ministry of Education and Culture.

\section{References}

Albright, J., Knezevic, L., \& Farrell, L. (2013). Everyday practices of teachers of English : A survey at the outset of national curriculum implementation, 36(2), 111-121.

Al-Daami, K., \& Wallace, G. (2007). Curriculum reform in a global context: a study of teachers in Jordan. Journal of Curriculum Studies, 39(3), 339-360. doi:10.1080/00220270601057790

Alok, K. (2012) Anchors for Educational Reforms. International Journal of Educational Reform 21(4), 276-291. 
Altinyelken, H. K. (2010). Curriculum change in Uganda: Teacher perspectives on the new thematic curriculum. International Journal of Educational Development, 30(2), 151-161. doi:10.1016/j.ijedudev.2009.03.004

Arslantas, H. I. (2011). Evaluation of elementary school inspectors' occupational helps and guidance to teachers about new curriculum, 6(February), 215-223.

Bantwini, B. D. (2010). How teachers perceive the new curriculum reform: Lessons from a school district in the Eastern Cape Province, South Africa. International Journal of Educational Development, 30(1), 83-90. doi:10.1016/j.ijedudev.2009.06.002

Basic Education Legislation 628/1998.

Beane, J. A. (1995). Toward a Coherent Curriculum (1995 ASCD Yearbook).

Bernelius, V. (2011). Osoitteenmukaisia oppimistuloksia?: kaupunkikoulujen eriytymisen vaikutus peruskoululaisten oppimistuloksiin Helsingissä. Yhteiskuntapolitiikka, 76(5), 479-493.

Biesta, G. (2013). Knowledge, judgement and the curriculum: on the past, present and future of the idea of the Practical. Journal of Curriculum Studies, 45(5), 684-696. doi:10.1080/00220272.2013.798839

Bobbitt, J. (1972). The curriculum. Boston: Houghton-Mifflin.

Bogner, A., \& Menz, W. (2009). Interviewing experts. Basingstoke: Palgrave Macmillan.

Broadhead, P. (2001). Curriculum Change in Norway: Thematic approaches, active learning and pupil cooperation - from curriculum design to classroom implementation. Scandinavian Journal of Educational Research, 45(1), 19-36. doi:10.1080/00313830020023375

Brundrett, M., \& Duncan, D. (2011). Leading curriculum innovation in primary schools. Management in Education, 25(3), 119-124. doi:10.1177/0892020610387957

Bulut, M. (2007). Curriculum Reform in Turkey: A Case of Primary School Mathematics Curriculum. Journal of Mathematics, Science and Technology Education.

Carl, A. (2005). The "voice of the teacher" in curriculum development : a voice crying in the wilderness?, 25(4), 223-228.

Chan, J. K. S. (2010). Teachers’ responses to curriculum policy implementation: Colonial constraints for curriculum reform. Educational Research for Policy and Practice, 9(2), 93106. doi:10.1007/s10671-010-9082-5

Cheung, A. C. K., \& Wong, P. M. (2011). Effects of school heads' and teachers' agreement with the curriculum reform on curriculum development progress and student learning in Hong Kong. International Journal of Educational Management, 25(5), 453-473.

Chin, R. (1976). The utility of system models and developmental models for practitioners. In W. G. Bennis, K. D. Benne, R. Chin, \& K. E. Corey (Eds.), The planning of change (3rd Editio., pp. 90-102). New York: Holt, Rinehart \& Winston. 
Chisholm, L. (2005). The making of South Africa's National Curriculum Statement. Journal of Curriculum Studies, 37(2), 193-208.

Chisholm, L., \& Leyendecker, R. (2008). Curriculum reform in post-1990s sub-Saharan Africa. International Journal of Educational Development, 28(2), 195-205.

Core Curriculum for Basic Education (2004). Read 2015, December 12. Available online: http://oph.fi/english/curricula_and_qualifications/basic_education.

Cuban, L. (1992). Curriculum stability and change. In P. W. Jackson (Ed.), Handbook of research on curriculum: a project of the American Educational Research Association (pp. 216-245). New York: MacMillan.

Datnow, a. (2005). The Sustainability of Comprehensive School Reform Models in Changing District and State Contexts. Educational Administration Quarterly, 41(1), 121-153.

Datnow, A., Stringfield, G., \& Borman, S. (2000). School Reform through a Highly Spesified Curriculum: Implementation and Effects of the Core Knowledge Sequence. The Elementary School Journal.

Dewey, J. (1959). Dewey on Education. Bureau of Publications, Teachers College, Columbia University.

Engeströn, Y. (2015, August) Expanding the objects from school to life: Educational research approaching crossroads. In R. Wegerif (Chair), Interplay of Teachers' Professional Competencies, Teaching Actions and Student Learning. Symposium conducted at EARLIconference, Limassol, Cypros.

Fernandez, T., Ritchie, G., \& Barker, M. (2008). A sociocultural analysis of mandated curriculum change: the implementation of a new senior physics curriculum in New Zealand schools. Journal of Curriculum Studies, 40(2), 187-213.

Finnish National Board of Education. (2015a). Curriculum 2016 web page. (2015, April 24). Retrieved from http://www.oph.fi/ops2016

Finnish National Board of Education. (2015b). Web page. (2015, May 25). Retrieved from http://www.oph.fi/english/about_fnbe

Fullan, M. (2007). The New Meaning of Educational Change (4th Editio.). New York: Teachers College Press.

Fullan, M., \& Miles, M. B. (1992). Getting Reform Right: What Works and What Doesn’t. Phi Delta Kappan, 73(10), 745-752.

Georgescu, D. (2008). Primary and secondary curriculum development in Afghanistan. Prospects, 37(4), 427-448. doi:10.1007/s11125-008-9058-x

Gerrard, J., \& Farrell, L. (2013). Remaking the professional teacher: authority and curriculum reform. Journal of Curriculum Studies, 46(5), 634-655. doi:10.1080/00220272.2013.854410 
Glacer, B. G. (1978). Theoretical sensitivity: Advances in methodology of grounded theory. Mill Valley, CA: Sociological Press.

Hamann, E. T., \& Lane, B. (2002). "We're From the State and We're Here to Help”: State-Level Innovations in Support of High School Improvement. Faculty Publications: Department of Teaching, Learning and Teacher Education, University of Nebraska. Paper 63.

Hammerness, K. (2006). From coherence in theory to coherence in practice. Teachers College Record, 108(7), 1241-1265. doi:10.1111/j.1467-9620.2006.00692.x

Hardarson, A. (2013). Equality and academic subjects. Journal of Curriculum Studies, 45(2), 119131.

Hargreaves, A. (2007). Sustainable Leadership and Development in Education: Creating the future, conserving the past. European Journal of Education, 42(2), 223-233.

Hargreaves, A., \& Fink, D. (2006). Sustainable leadership. San Francisco: Jossey Bass.

Hargreaves, A. \& Shirley, D. (2009) The Fourth Way, Thousand Oaks, CA; Corwin Press.

Hopmann, S. T. (2003) On the evaluation of curriculum reforms. Journal of Curriculum Studies, 35(4), 459-478.

Jackson, P. (1992). Handbook of research on curriculum: A project of the American Educational Research Association. New York: MacMillan.

Johannesson, I. A., Lindblad, S. \& Simola, H. (2002) An Inevitable Progress? Educational restructuring in Finland, Iceland and Sweden at the turn of the millennium. Scandinavian Journal of Educational Research, 46(3), 325-339.

Kelly, A. V. (2004). The curriculum theory and practice (5th Editio.). Thousand Oaks: SAGE.

Koretz, D. (2005). Alignment, High Stakes, and the Inflation of Test Scores (Vol. CSE Report).

Korkmaz, I. (2008). Evaluation of teachers for restructured elementary curriculum (grades 1 to 5). Education, 129(2), 205-258.

Korotkov, D. L. (1998). The sense of coherence: Making sense out of chaos. In P. T. P. Wong \& P. S. Fry (Eds.), The human quest for meaning: A handbook of psychological research and clinical applications (pp. 51-70). Mahwah: Lawrence Erlbaum Associates Publishers.

Lawton, D. (1973). Social change, Educational Theory and Curriculum planning. London: Hodden and Stoughton.

Li, Q., \& Ni, Y. (2011). Impact of curriculum reform: Evidence of change in classroom practice in mainland China. International Journal of Educational Research, 50(2), 71-86.

doi:10.1016/j.ijer.2011.06.003 
Merkens, H., Geppert, M. and Antal, D. (2001). Triggers of organizational learning during the transformation process in central European countries, in Dierkes, M., Berthoin Antal, A., Child, J. and Nonaka, I. (Eds.) The Handbook of Organizational Learning and Knowledge, Oxford University Press, Oxford, pp. 242-63.

Miles, M. B., \& Huberman, A. M. (1984). Qualitative data analysis. A Sourcebook of New Methods. Newbury Park: SAGE.

Molstad, C.E. (2015). State-based curriculum-making: approaches to local curriculum work in Norwey and Finland. Journal of Curriculum Studies, 47(4), 441-461. DOI: 10.1080/00220272.2015.1039067.

National Institute for Health and Welfare. (2013). Retrieved from: https://www.thl.fi/fi/web/thlfi-en

Nevalainen, R., Kimonen, E., \& Hämäläinen, S. (2001). Curriculum Changes in the Finnish Comprehensice School. The Lessons of Three Decades. In E. Kimonen (Ed.), Curriculum approaches. Readings and activities for educational studies. (pp. 123-141). University of Jyväskylä. Department of Teacher Education and Institute for Educational Research.

Newmann, F. M., Smith, B., Allensworth, E., \& Bryk, a. S. (2001). Instructional Program Coherence: What It Is and Why It Should Guide School Improvement Policy. Educational Evaluation and Policy Analysis, 23(4), 297-321. doi:10.3102/01623737023004297

Ng, S. W. (2009). Why did principals and teachers respond differently to curriculum reform? Teacher Development, 13(3), 187-203.

Ni, Y., Li, Q., Li, X., \& Zhang, Z.-H. (2011). Influence of curriculum reform: An analysis of student mathematics achievement in Mainland China. International Journal of Educational Research, 50(2), 100-116. doi:10.1016/j.ijer.2011.06.005

Niemi, H., Toom. A. \& Kallioniemi, A. (Eds.) (2012). Miracle of education. The principles and practices of teaching and learning in Finnish schools. Rotterdam: Sense Publishers.

OECD (2013), Education at a Glance 2013: OECD Indicators, OECD Publishing. http://dx.doi.org/10.1787/eag-2013-enOECD. (2012).

OECD (2012), Education at a Glance 2012: OECD Indicators, OECD Publishing. http://dx.doi.org/10.1787/eag-2012-en

Pahkin, Vanhala, \& Lindström. (2007). Opettajien työssä jaksaminen ja jatkaminen - QPS NordicADW - Monitoring Age Diverse Workforce. Työterveyslaitos.

Patton, M. Q. (1990). Qualitative evaluation and research methods (2nd Editio.). Newbury Park: SAGE.

Priestley, M. (2011). Schools, teachers, and curriculum change: A balancing act? Journal of Educational Change, 12(1), 1-23. doi:10.1007/s10833-010-9140-z

Priestley, M. \& Biesta, G. (eds) (2013) Reinventing the Curriculum: New Trends in Curriculum Policy and Practice London: Bloomsbury. 
Pyhältö, K., Soini, T., \& Pietarinen, J. (2013). Do comprehensive school teachers perceive themselves as active agents in school reforms? Journal of Educational Change, 13(1), 95-116.

Ramparsad, R. (2005). A strategy for teacher involvement in curriculum development. South African Journal of Education, 21(4), 287-292.

Rogan, J., \& Aldous, C. (2005). Relationships between the constructs of a theory of curriculum implementation. Journal of Research in Science Teaching, 42(3), 313-336. doi:10.1002/tea.20054

Rogan, J. M. (2007). An uncertain harvest: a case study of implementation of innovation. Journal of Curriculum Studies, 39(1), 97-121. doi:10.1080/00220270500532448

Rosenmund, M. (2000). OP-ED Approaches to international comparative research on curricula and curriculum-making processes. Journal of Curriculum Studies, 32(5), 599-606. doi:10.1080/00220270050116905

Saari, A., Salmela, S. \& Vilkkilä, J. (2014) Governing Autonomy: Subjectivity, Freedom, and Knowledge in Finnish Curiculum Discourse. In W. Pinar (Ed.) International Handbook of Curriculum Research. NY: Taylor \& Francs, 183-200.

Sahlberg, P. (2011a). Finnish lessons. New York: Teachers College Press.

Sahlberg, P. (2011b). The Fourth Way of Finland. Journal of Educational Change, 12(2), 173-185. doi:10.1007/s10833-011-9157-y

Salmela-Aro, K., Kiuru, N., Pietikäinen, M., \& Jokela, J. (2008). Does school matter? The role of school context in adolescents' school-related burnout. European Psychologist, 13(1), 12-23.

Sannino, A. (2010). Teachers' talk of experiencing: Conflict, resistance and agency. Teaching and Teacher Education, 26, 838-844.

Saracaloğlu, S., Yılmaz, S., Çengel, M., Çöğmen, S., Karademir, Ç. A., \& Kanmaz, A. (2010). Elementary teachers' views about their roles in curriculum development and evaluation process: The case of Denizli. Procedia - Social and Behavioral Sciences, 2(2), 2427-2434. doi:10.1016/j.sbspro.2010.03.349

Saylor, J. G., Alexander, W. M., \& Lewis, A. J. (1981). Curriculum planning. For better teaching and learning (4th Editio.). New York: Holt, Rinehart and Winston.

Schiro, M. S. (2008). Curriculum Theory. Conflicting Visions and Enduring Concerns. Los Angeles: SAGE.

Schmidt, M., \& Datnow, A. (2005). Teachers’ sense-making about comprehensive school reform: The influence of emotions. Teaching and Teacher Education, 21(8), 949-965. doi:10.1016/j.tate.2005.06.006

Shah, R. (2012). Goodbye conflict, hello development? Curriculum reform in Timor-Leste. International Journal of Educational Development, 32(1), 31-38. doi:10.1016/j.ijedudev.2011.04.005 
Shen, J., \& Ma, X. (2006). Does Systemic Change Work? Curricular and Instructional Practice in the Context of Systemic Change. Leadership and Policy in Schools.

Simola, H. (2005) The Finnish miracle of PISA: historical and sociological remarks on teaching and teacher education, Comparative Education, 41:4, 455-470, DOI:10.1080/03050060500317810.

Simola, H., Rinne, R., Varjo, J., \& Kauko, J. (2013). The paradox of the education race:How to win the ranking game by sailing to headwind. Journal of Education Policy, 28, 612-633. doi:10.1080/02680939.2012.758832

Sivesind, K. (2010). No Title. Journal of Curriculum Studies, 26(838-844).

Soini, T., Pietarinen, J., \& Pyhältö, K. (2013). Design research approach in the large scale educational innovations. In I. R. Haslam, S. K. Myint, \& I. M. Saleh (Eds.), Large scale reform and social capital building: The professional development imperative (pp. 70-92).

Soini, T., Pietarinen, J., Pyhältö, K., Westling, S.-K., Ahonen, E., \& Järvinen, S. (2012). Mitä jos opettaja etääntyy työstään? Näkökulmia opettajan työhön kiinnittymiseen. Nuorisotutkimus, 30(2), 5-20.

Spillane, J. P., Reiser, B. J., \& Reimer, T. (2002). Policy Implementation and Cognition: Reframing and Refocusing Implementation Research. Review of Educational Research, 72(3), 387-431. doi:10.3102/00346543072003387

Stenhouse, L. (1975). An Introduction to Curriculum Research and Development. London: Heinemann.

Toom, A. \& Husu, J. (2012) Finnish teachers as 'makers of the many'. Balancing between Broad Pedagogical Freedom and Responsibility. In Niemi, H., Toom, A. \& Kallioniemi, A. (Eds.) Miracle of Education. Rotterdam: Sense Publishers, 39-54.

Tyler, R. (1949). Basic principles of curriculum and instruction. Chicago: University of Chicago Press.

Walker, M., \& Soltis, J. F. (1997). Curriculum and Aims. Columbia: Teachers College Press.

Wallace, C. S., \& Priestley, M. (2011). Teacher beliefs and the mediation of curriculum innovation in Scotland: A socio-cultural perspective on professional development and change. Journal of Curriculum Studies, 43(3), 357-381. doi:10.1080/00220272.2011.563447

Wallace, J., Sheffield, R., Rénnie, L., \& Venville, G. (2007). Looking back, looking forward: Researching the conditions for curriculum integration in the middle years of schooling. The Australian Educational Researcher, 34(2), 29-49. doi:10.1007/BF03216856

Weiler, H. N. (1990). Curriculum reform and the legitimation of educational objectives: The case of the Federal Republic of Germany. Oxford Review of Education, 16(1), 1-14.

Westbury, L. (2008). Making curricula. Whu do stated make curricula, and how? In F. M. Conelly (Ed.), The SAGE Handbook of Curriculum and Instruction (pp. 45-65). Thousand Oaks: SAGE. 
Vitikka, E. (2009). Opetussuunnitelman mallin jäsennys. Sisältö ja pedagogiikka kokonaisuuden rakentajina. University of Helsinki.

Yusuf, C. (2013). Relationship between Teachers' Self-Efficacy Beliefs and Their Willingness to Implement Curriculum Reform. International Journal of Educational Reform, 22(3), 252-270. 
Table 1. Issues ( $\mathrm{n}=258$ ) among triggers and aims, as perceived by the administrators.

\begin{tabular}{lccc}
\hline & $\begin{array}{c}\text { TRIGGERS } \\
\text { Preserve }\end{array}$ & $\begin{array}{c}\text { TRIGGERS } \\
\text { React to }\end{array}$ & $\begin{array}{c}\text { AIMS } \\
\text { Work towards }\end{array}$ \\
\hline Pedagogy & 13 & 28 & 37 \\
The school & 30 & 38 & 32 \\
Society & 15 & 42 & 23 \\
Total & 58 & 108 & 92 \\
\hline
\end{tabular}


Table 2. Triggers and aims at the level of pedagogy, as perceived by the administrators $(n=23)$.

\begin{tabular}{|l|l|l|}
\hline Pedagogy & $\begin{array}{l}\text { TRIGGERS } \\
\text { Preserve }\end{array}$ & $\begin{array}{l}\text { Subject domain (10/23) } \\
\text { Good quality teaching and teacher-student interaction (8/23) } \\
\text { Non-standardized assessment (3/23) }\end{array}$ \\
\cline { 2 - 3 } & $\begin{array}{l}\text { TRIGGERS } \\
\text { React to }\end{array}$ & $\begin{array}{l}\text { The teacher-, classroom-, and text-book-oriented approach to } \\
\text { learning (19/23) } \\
\text { Subject-based orientation (12/23) } \\
\text { Assessment issues (5/23) } \\
\text { Lack of individual support (5/23) }\end{array}$ \\
& AIMS & $\begin{array}{l}\text { Pupil-centredness (20/23) } \\
\text { Collaborative learning (19/23) } \\
\text { Developing subject integration and coherence (16/23) } \\
\text { Developing individual subjects (9/23) } \\
\text { Versatile assessment (7/23) } \\
\text { Parity in assessment (5/23) }\end{array}$ \\
\cline { 2 - 3 } & & \\
& &
\end{tabular}


Table 3. Triggers and aims at the school-level, as perceived by the administrators $(n=23)$.

\begin{tabular}{|c|c|c|}
\hline \multirow[t]{3}{*}{ School } & $\begin{array}{l}\text { TRIGGERS } \\
\text { Preserve }\end{array}$ & $\begin{array}{l}\text { Good schools in general (15/23) } \\
\text { Skilful teachers (15/23) } \\
\text { Equal schools for all pupils (15/23) } \\
\text { A functional steering system and strategy in education (14/23) } \\
\text { Pupils' well-being (9/23) } \\
\text { Collaboration with parents and multi-professional networks (3/23) }\end{array}$ \\
\hline & $\begin{array}{l}\text { TRIGGERS } \\
\text { React to }\end{array}$ & $\begin{array}{l}\text { Old-fashioned schools (16/23) } \\
\text { Pupils’ and teachers’ well-being issues (14/23) } \\
\text { Non-functional steering system and strategy in education (11/23) } \\
\text { Decreasing equality for pupils (9/23) }\end{array}$ \\
\hline & $\begin{array}{l}\text { AIMS } \\
\text { Work towards }\end{array}$ & $\begin{array}{l}\text { More collaboration and interaction within schools (15/23) } \\
\text { System-wide instructional and pedagogical steering and leadership } \\
(13 / 23) \\
\text { Increased well-being in schools (13/23) } \\
\text { Clarification of schools' missions and values (9/23) } \\
\text { More collaboration and interaction with parents and } \\
\text { multi-professional networks (8/23) } \\
\text { Teachers' increased competences (7/23) }\end{array}$ \\
\hline
\end{tabular}


Table 4. Triggers and aims at the societal level, as perceived by the administrators $(n=23)$.

\begin{tabular}{|l|l|l|}
\hline Society & $\begin{array}{l}\text { TRIGGERS } \\
\text { Preserve }\end{array}$ & $\begin{array}{l}\text { A strong school system when compared internationally (11/23) } \\
\text { Strong, master's-level teacher education (9/23) } \\
\text { Appreciation of schools as builders of the country (8/23) } \\
\text { Supportive political decisions (7/23) }\end{array}$ \\
\cline { 2 - 3 } & $\begin{array}{l}\text { TRIGGERS } \\
\text { React to }\end{array}$ & $\begin{array}{l}\text { Changing world (20/23) } \\
\text { Societal needs and problems (17/23) } \\
\text { Non-supportive political decisions (12/23) } \\
\text { Lack of proper resourcing in education (12/23) } \\
\text { Insufficient teacher education (5/23) } \\
\text { Decreasing appreciation of schools (1/23) }\end{array}$ \\
\cline { 2 - 3 } & $\begin{array}{l}\text { AIMS } \\
\text { Work towards }\end{array}$ & $\begin{array}{l}\text { Schools as producers of multiple competences and skills (19/23) } \\
\text { Increased role of schools in building the country/world (7/23) } \\
\text { Schools as a source of individual growth (6/23) } \\
\text { Less detailed teacher education (1/23) } \\
\text { Supportive political decisions (1/23) }\end{array}$ \\
\hline
\end{tabular}


Appendix 1. The interview questions

If you think about comprehensive school in Finland, how do you see it at the moment?

What are the key challenges in its development? Which things do you feel are in good order?

In what direction is the comprehensive school developing in your opinion?

You are taking part in the reform of the national core curriculum. How do you think the national core curriculum of the comprehensive school should be reformed? Why?

How do you wish to see the new national core curriculum in the daily life of the school? In your opinion, what kinds of things in the operation of the school should be changed in particular? Why?

What do you think about the draft prepared by your working group? How is the curriculum about to change?

What things in the national core curriculum do you especially wish to influence? Why?

At the end of the interview, think about the significance of the reform of the national core curriculum. 